\title{
ДОШКОЛЬНОЕ ОБРАЗОВАНИЕ
}

УДК 373.2

ББК 74.1

DOI: 10.33065/2307-1052-2019-3-29-34-39

\section{Педагогические условия развития хореографических умений у детей старшего дошкольного возраста в дополнительном образовании}

\author{
Андрианова Елена Ивановна, \\ кандидат педагогических наук, доцент кафедры дошкольного и начального общего \\ образования, Ульяновский государственный педагогический университет имени \\ И. Н. Ульянова, г. Ульяновск, Россия
}

\section{Хорева Анастасия Николаевна,} магистрант факультета педагогики и психологии, Ульяновский государственный педагогический университет имени И. Н. Ульянова, г. Ульяновск, Россия

Аннотация: В статье описана опытно-экспериментальная работа по развитию хореографических умений у детей старшего дошкольного возраста, определены педагогические условия, способствующие развитию хореографических умений у старших дошкольников в условиях студийной работы. Получено подтверждение гипотезе о том, что развитие хореографических умений старших дошкольников в процессе студийной работы будет эффективнее, чем при традиционной форме.

Ключевые слова: художественно-эстетическое развитие дошкольников, дополнительное образование, хореографические умения старших дошкольников, процесс организации студийной работы, педагогические условия развития хореографических умений у старших дошкольников, взаимодействие с родителями воспитанников.

\section{Pedagogical Conditions for Developing Choreographic Skills of Preschool Children in Additional Education}

\section{Andrianova Elena I.,}

Candidate of Pedagogical Sciences, Associate Professor, Department of Preschool and Primary General Education, Ulyanovsk State Pedagogical University named after I.N. Ulyanov, Ulyanovsk, Russia

\section{Khoreva Anastasia N.,} Master student, School of Pedagogy and Psychology, Ulyanovsk State Pedagogical University named after I. N. Ulyanov, Ulyanovsk, Russia 
Abstract. The article describes the experimental work on the development of choreographic skills of older preschool children. It defines the pedagogical conditions that contribute to the development of choreographic skills of older preschoolers within studio work. This confirms the hypothesis that the development of choreographic skills of preschoolers within the process of studio work will be more effective than within the traditional form.

Keywords: artistic and aesthetic development of preschool children, additional education, choreographic skills of senior preschoolers, the process of organizing studio work, pedagogical conditions for the development of choreographic skills of senior preschoolers, interaction with parents of pupils.

Актуальность исследования. Художественно-эстетическое развитие, согласно ФГОС дошкольного образования, является важнейшей областью развития ребенка [ФГОС ДО]. Оно предполагает развитие восприятия и понимания произведений искусства, «становление эстетического отношения к окружающему миру, формирование элементарных представлений о видах искусства, реализацию самостоятельной творческой деятельности детей» [Левина Л. Э. , Курашинова 2016: 151].

Дошкольный возраст особенно восприимчив к музыке и танцу, поэтому занятия хореографией приобретают все большее распространение в практике современного дошкольного образования. При этом, согласно нормативно-правовой базе дошкольного образования, хореография не является обязательной образовательной областью, реализуемой в детских садах, поэтому вводится в процесс воспитания как дополнительная. Особенностью дополнительного образования является добровольный выбор детьми наиболее привлекательного вида деятельности, и именно поэтому оно позволяет дошкольникам максимально творчески реализовать себя.

Эффективность художественно-эстетического образования детей дошкольного возраста при помощи музыки и танцев отмечают многие исследователи [Гогоберидзе 2005; Горшкова 2003; Давыдова 2006; Левина, Курашинова 2016; Мартыненко 2005; Нечаева 2015; Пуртова 2003; Радынова 1997; Тарасова 1988; Чурашов 2013; Юнусова 2011], при этом тема педагогических условий развития хореографических умений детей старшего дошкольного возраста в условиях студийной работы в контексте дополнительного образования не является в достаточной степени изученной.

Актуальность проблемы на социально-педагогическом уровне обусловлена тем, что социальный заказ государства, согласно ФГОС ДО, направлен на развитие социально-активной личности ребенка, а такую личность можно воспитать только в творческой деятельности. Именно такой деятельностью является хореография.

На научно-теоретическом уровне актуальность исследования определяется недостаточной научной обоснованностью педагогических условий, необходимых для развития хореографических способностей дошкольников на студийных занятиях.

На научно-методическом уровне актуальность исследования связана с недостаточным методическим обеспечением деятельности педагогов по реализации программ дополнительного хореографического образования.

Цель исследования - теоретическое и экспериментальное обоснование педагогических условий развития хореографических умений детей старшего дошкольного возраста в условиях студийной работы в контексте дополнительного образования.

В качестве гипотезы исследования было выдвинуто предположение, что развитие хореографических умений у детей старшего дошкольного возраста в дополнительном 
образовании будет более эффективным при соблюдении следующих педагогических условий: учете принципов дидактики (доступности, наглядности, индивидуального подхода, движения от простого к сложному и т.п.) при построении занятий; использовании танцевального репертуара сюжетного и игрового содержания; использовании движений различных направлений хореографии (классического, народного, бального и современного танцев); интеграции разнообразных видов детской деятельности при развитии хореографических умений (художественно-декоративной при создании костюмов, импровизационной, участия в шоу-программах), способствующих повышению самооценки ребенка, развитию уверенности в собственных силах; создании непринужденной, эмоционально-положительной обстановки в процессе взаимодействия с детьми, атмосферы праздника в работе с воспитанниками; организации тесного сотрудничества с родителями в процессе проведения занятий, выступлений, досуговых мероприятий студии.

Onисание эксперимента. Опытно-экспериментальное исследование проводилось на базе МБДОУ № 58 «Снежок» г. Ульяновска и танцевальной студии «Dozorova» Д. А. Дозоровой. В исследовании принимали участие 20 детей старшего дошкольного возраста. Контрольную группу (10 человек) составили воспитанники МБДОУ № 58 «Снежок» г. Ульяновска, экспериментальную (10 человек) - воспитанники танцевальной студии «Dozorova» Д. А. Дозоровой. В МБДОУ № 58 г. Ульяновска художественно-эстетическое развитие дошкольников осуществляется в соответствии с ФГОС ДО с помощью парциальной программы «Ладушки» [Каплунова, Новоскольцева 2010]. Развитие хореографических умений старших дошкольников в танцевальной студии «Dozorova» осуществляется Д. А. Дозоровой, выпускницей хореографического отделения УлГУ и владелицей студии танца. Дарья Алексеевна является кандидатом в мастера спорта по спортивно-бальным танцам, обладателем «S» класса по спортивно-бальным танцам, многократной чемпионкой Ульяновской области и призером всероссийских турниров. В студии «Dozorova» сформирован собственный коллектив детей 5 - 7 лет - ансамбль эстрадного танца.

При определении уровня развития хореографических умений старших дошкольников на констатирующем этапе эксперимента были использованы критерии, выделенные на основании исследований О. П. Радыновой, И. М. Каплуновой, И. А. Новоскольцевой: умение слушать музыкальное произведение, умение различать ритм музыкального произведения; умение выполнять танцевальные движения; умение «инсценировать игровые песни, придумывать варианты образных движений в играх», танцах и хороводах [Базанова 2017]. После выделения критериев были определены уровни развития хореографических умений у старших дошкольников: высокий, средний и низкий.

Высокий уровень. Ребенок внимательно слушает произведение от начала до конца, передает эмоционально-образное содержание музыкального произведения, выражает свои мысли и чувства в речи, называет жанр, характер произведения и его выразительные особенности. Ребенок четко реагирует на ритм, воспроизводит его в танце, передает движениями характер музыки, меняет движения корпуса, головы, рук и ног. Ребенок хорошо ориентируется в характере музыки, марширует в соответствии с ритмом, соблюдает правильные дистанции друг от друга, самостоятельно перестраивается, «выполняет требуемые перемены направления и темпа движения, руководствуясь музыкой» [Базанова 2017].

Ребенок хорошо владеет основными музыкально-ритмическими движениями, согласно возрасту и программным требованиям: «шаг с притопом, приставной шаг с 
приседанием, пружинящий шаг, боковой галоп, переменный шаг». Умеет перестраиваться в заданном направлении, легко на носочках бежать [Базанова 2017].

Ребенок умеет сохранять правильное положение корпуса, рук, ног при исполнении танцевальных движений, исполнять танцевальные движения индивидуально и коллективно, с музыкальным сопровождением и без него. Самостоятельно начинает движение после музыкального вступления без подсказки педагога. Выразительно и ритмично исполняет танцы репертуарного плана. Ребенок непринужденно выполняет элементы танца, «передавая в игровых, плясовых движениях различные нюансы музыки - напевность, грациозность, энергичность, нежность, игривость» [Базанова 2017].

Ребенок умеет «выразительно и одухотворенно передавать танцевальные образы, используя средства хореографии; умеет импровизировать под незнакомую музыку; умеет создавать новые танцевальные движения, интерпретировать знакомые движения; умеет составлять танцевальные композиции на основе наработанного хореографического материала» [Юнусова 2011].

Средний уровень. Ребенок передает эмоционально-образное содержание музыкального произведения, слушает произведение от начала до конца, иногда отвлекается, в целом выражает свои мысли и чувства.

Ребенок правильно реагирует на ритм, воспроизводит его в деятельности не всегда точно, слушает не всегда внимательно, проводит частичный музыкальный анализ произведения. Допускает ошибки в определении характера и жанра произведения.

Ребенок в основном владеет основными музыкально-ритмическими движениями, согласно возрасту и программным требованиям: «шаг с притопом, приставной шаг с приседанием, пружинящий шаг, боковой галоп, переменный шаг». Умеет перестраиваться в заданном направлении, легко на носочках бежать.

Ребенок начинает движение после музыкального вступления с подсказкой педагога, с трудом передает выразительные особенности музыки в танце, умеет двигаться под музыку, но не эмоционально. Затрудняется в придумывании вариантов образных движений в играх и хороводах [Базанова 2017].

Низкий уровень. У ребенка нет заинтересованности в музыкально-ритмической деятельности, он многократно ошибается в выполнении задания на воспроизведение ритма музыкального произведения или с заданием не справляется, эмоционально неактивен, двигательная активность на музыку мала. Элементы танца выполняет с ошибками. Начинает движение самостоятельно после музыкального вступления только с подсказкой педагога. Не может придумать варианты образных движений в играх и хороводах.

Диагностика включала три серии заданий: задания для определение уровня развития чувства ритма, уровня развития музыкально-ритмических движений и для определения уровня развития творческих хореографических умений.

Диагностика детей контрольной группы детей в МБДОУ № 58 показала, что высокий уровень развития хореографических умений имеют 2 ребенка, что составляет 20 \%, средний уровень - 5 детей (50 \%), низкий уровень - 3 ребенка (30 \%). Диагностика детей экспериментальной группы, воспитанников танцевальной студии «Dozorova» Д.А. Дозоровой, показала, что высокий уровень развития хореографических умений имеет 1 ребенок, что составляет $10 \%$, средний уровень - 6 детей (60\%), низкий уровень - 3 ребенка (30\%).

Данные констатирующего этапа эксперимента, проведенного в начале учебного 2018 - 2019 года, показали, что у дошкольники в основном находятся на среднем и низком уровнях развития хореографических умений. 
На формирующем этапе эксперимента была поставлена цель развить хореографические умения воспитанников танцевальной студии «Dozorova» Д. А. Дозоровой путем проведения цикла музыкально-игровых занятий и экспериментально проверить гипотезу исследования. В течение учебного года с воспитанниками танцевальной студии «Dozorova» два раза в неделю проводилась музыкально-игровая деятельность длительностью 60 минут. Занятия студии «Dozorova» были поделены на блоки, подчиненные тематическому планированию образовательной работы. Первый блок - подготовительный. Он носил игровой характер, помогая детям быстрее влиться в новый учебный процесс. Второй блок был посвящен празднику «Хэллоуин» в танцевальной студии. Он состоял из четырех занятий, на которых дети познакомились с произведениями выдающихся композиторов (А. Вивальди, П. Чайковского, С. Прокофьева). После прослушивания композиций детям было предложено проанализировать произведения, определить их характер и, в заключение, показать хореографическую импровизацию на понравившийся фрагмент. Все ребята успешно с этим справились. В декабре осуществлялась постановка хореографических композиций, посвященных празднованию Нового года. В следующем блоке дети познакомились с прекрасным миром балета, с выдающимися танцорами и основными балетными движениями и позициями. С середины января и до конца февраля реализовывался блок «Современный танец», осуществлялась постановка современных эстрадных танцев и готовилось выступление воспитанников в Центре поддержки и развитии детского, юношеского и взрослого творчества «Страна Детства». Дети активно готовились к Всероссийскому Фестивалю детского и взрослого творчества «АртКульт». Следующие блоки предполагали стрейчинг, изучение элементов народных и бальных танцев и т.п. Итогом работы студии стало открытое занятие для родителей и педагогов в мае, на котором дети исполнили парный бальный танец.

За короткое время существования ансамбля дети, которые никогда не занимались танцами, освоили и открыли для себя множество танцевальных направлений, стали увереннее в себе, сплотились, и на первом конкурсе заняли сразу третье место среди двенадцати коллективов. Предположительно, это произошло потому, что у педагогов студии танца выстроились тесные связи с родителями детей, что видно из их общения в закрытом чате в социальных сетях, связанного с обсуждением вопросов организации работы ансамбля, пошива костюмов и предстоящих выходах детей на сцену.

В течение учебного года в студии часто проводились досуговые мероприятия, такие как Хэллоуин, Новый Год, Пижамная вечеринка, творческие мастер-классы. Вся деятельность танцевальной студии «Dozorova» широко освещалась в социальных сетях, где можно было наблюдать за успехами ребят и узнавать об их достижениях. Таким образом, экспериментальная работа в танцевальной студии «Dozorova» включала использование разнообразных видов музыкальной активности детей, широкого танцевального репертуара, установление тесного контакта педагогов с родителями и т.п.

На контрольном этапе эксперимента была проведена повторная диагностика уровня развития хореографических умений у детей экспериментальной и контрольной групп с использованием той же методики, критериев и уровней, что и на констатирующем этапе.

Диагностика детей контрольной группы (воспитанники МБДОУ №58) показала, что высокий уровень развития хореографических умений продемонстрировали 20 \% обследованных, средний уровень - 60 \%, низкий - 20 \%.Диагностика детей экспериментальной группы (воспитанники танцевальной студии «Dozorova» Д. А. Дозоровой) показала, что высокий уровень развития хореографических умений продемонстрировали 40 \% обследованных, средний уровень - 60 \%, низкий уровень развития хореографических умений 
не выявлен. Таким образом, показатели развития хореографических умений у детей экспериментальной группы оказались значительно выше, чем у детей контрольной группы, что подтвердило нашу гипотезу о том, что эффективность развития хореографических умений у старших дошкольников, посещающих студию, будет более высокой, чем у детей, занимающихся по программе дошкольного учреждения в соответствии с ФГОС ДО.

\section{Источники и литература:}

1. Гогоберидзе А. Г. Теория и методика музыкального воспитания для детей дошкольного возраста: учеб. пособие для студентов высших учеб. заведений. М.: Академия, 2005. 320 с.

2. Горшкова Е. В. От жеста к танцу: пособие для муз. рук. ДОУ. М.: ГНОМ и Д, 2003. 78 с.

3. Давыдова М. А. Музыкальное воспитание в детском саду: средняя, старшая и подготовительные группы. M.: BAKO, 2006. 240 c.

4. Каплунова И., Новоскольцева И. Ладушки. Программа по музыкальному воспитанию детей дошкольного возраста. СПб.: Невская нота, 2010. 64 с.

5. Левина Л. Э., Курашинова С.Г. Художественно-эстетическое воспитание дошкольников средствами изобразительной деятельности. // Концепт. 2016. № 10. С. 151 - 155.

6. Мартыненко Е. В. Педагогические условия формирования хореографических умений детей 5 - 6 летнего возраста в дошкольных учреждениях: автореф. дис... канд. пед. наук. Бердянск, 2005. 24 с.

7. Нечаева Т. Б. Развитие ритмопластики у дошкольников в условиях дополнительного образования: автореф. канд. пед. наук. Екатеринбург, 2015. 24 с.

8. Базанова А. В. Программа кружка «Барбарики». Егорьевск, 2017. [Электронный ресурс].// URL: https:// egords15.edumsko.ru/uploads/2000/1040/section/46723/66406/Programma.docх (дата обращения 20.05.2019).

9. Пуртова Т. В. Учите детей танцевать: учеб. пособие. М.: ВЛАДОС, 2003. 256 с.

10. Радынова О. П. Музыкальное развитие детей. М.: ВЛАДОС, 1997.608 с.

11. Тарасова К. В. Онтогенез музыкальных способностей. М. : Педагогика, 1988.176 с.

12. Федеральный государственный образовательный стандарт дошкольного образования. [Электронный ресурс].// URL: http://kortobrazovanie. ucoz.ru/news/proekt_fgos_doshkolnogo_obrazovanija (дата обращения: 17.05.2019).

13. Чурашов А. Г. Художественно-эстетическое развитие детей старшего дошкольного возраста в дополнительном образовании средствами хореографии: автореф. канд. пед наук. Челябинск, 2013. 27 с.

14. Юнусова Е. Б. Автореферат диссертации «Становление хореографических умений у детей старшего дошкольного возраста в дополнительном образовании». Челябинск, 2011. 27 с. 